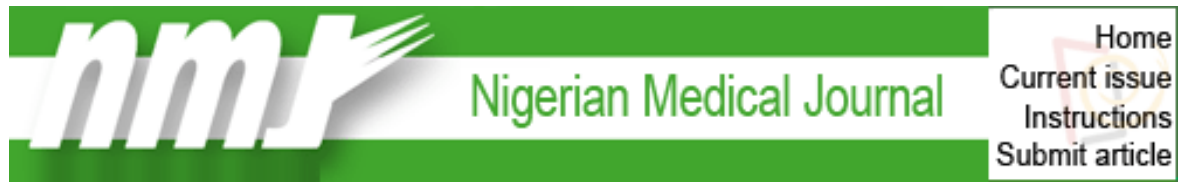

\title{
Effect of automated red cell exchanges on oxygen saturation on-air, blood parameters and length of hospitalization in sickle cell disease patients with acute chest syndrome
}

\author{
$\underline{\text { John C. Aneke, }}{ }^{1,2}$ Nancy Huntley, $^{2}$ John Porter, $^{2}$ and Perla Eleftheriou $^{2}$ \\ ${ }^{1}$ Department of Haematology, Nnamdi Azikiwe University Teaching Hospital, Nnewi, Nigeria \\ 2 Department of Haematology, Red Cell Unit, University College London Hospital, London, UK \\ Address for correspondence: Dr. John C. Aneke, Department of Haematology, Nnamdi Azikiwe University Teaching Hospital, PMB 5025, \\ Nnewi, Anambra, Nigeria. E-mail: anekejc@gmail.com
}

Copyright : () 2016 Nigerian Medical Journal

This is an open access article distributed under the terms of the Creative Commons Attribution-NonCommercial-ShareAlike 3.0 License, which allows others to remix, tweak, and build upon the work non-commercially, as long as the author is credited and the new creations are licensed under the identical terms.

\section{Abstract}

\section{Background:}

Red cell exchanges (RCEs) lead to improvement in tissue oxygenation and reduction in inflammatory markers in sickle cell disease (SCD) patients who present with acute chest syndrome (ACS). The aim of this study is to evaluate the effects of automated-RCE (auto-RCE) on oxygen saturation $\left(\mathrm{SpO}_{2}\right)$ on-air, blood counts, the time to correct the parameters and length of hospitalization after the exchange in SCD patients presenting with ACS.

\section{Subjects and Methods:}

This was 2 years study involving five SCD patients; the time for $\mathrm{SpO}_{2}$ on air to increase to $\geq 95 \%$ and chest symptoms to resolve, postprocedure, as well as the length of in-patient hospitalization was recorded. All data were entered into Statistical Package for Social Sciences Version 20.0 (SPSS Inc., Chicago, IL, USA) computer software for analyses.

\section{Results:}

The study involved $4(80 \%)$ hemoglobin ( $\mathrm{Hb}) \mathrm{SS}$ and $1(20 \%) \mathrm{HbSC}$ patients. The median time of $\mathrm{SpO}_{2}$ recovery was $24 \mathrm{~h}$, ranging from 6 to $96 \mathrm{~h}$. About 60\% (3/5) of patients achieved optimal $\mathrm{SpO}_{2}$ within $24 \mathrm{~h}$ post-RCE, while discharge from intensive care unit was $24 \mathrm{~h}$ after auto-RCE in one patient. The $\mathrm{Hb}$ concentration was significantly higher, while the total white cell and absolute neutrophil counts were significantly lower at the time of resolution of symptoms, compared to before auto-RCE $(P<0.05)$. The average post auto-red cell transfusion symptoms duration was 105.6 (24-240) h while mean inpatient stay was $244.8(144-456) \mathrm{h}$.

\section{Conclusion:}

Auto-RCE could reverse hypoxia in ACS within $24 \mathrm{~h}$.

Keywords: Acute chest syndrome, auto-red cell exchange, oxygen saturation, sickle cell disease

\section{INTRODUCTION}

Sickle cell disease (SCD) is an autosomal recessive genetic disorder in which there is the homozygous inheritance of the sickle hemoglobin ( $\mathrm{HbS}$ ) or in association with any other abnormal $\mathrm{Hb} .{ }^{\underline{1}}$ The hallmarks 
7/20/2017 Effect of automated red cell exchanges on oxygen saturation on-air, blood parameters and length of hospitalization in sickle cell disease pa...

of this disorder include recurrent acute events known as crises which interrupts steady chronic anemia.

Repeated crises and persistent anemia have been shown to predispose to significant end-organ dysfunction, particularly in the homozygous (HbSS) state of the disease. ${ }^{1,2}$ Sickle red cells when exposed to reduced oxygen tension assume an abnormal, rigid (sickle) shape that adhere together with platelets and white blood cells (WBCs) to the endothelial wall, leading to vascular occlusion, ischemia, and endothelial dysfunction. $, \underline{2}, \underline{3}$

Acute chest syndrome (ACS) is a potentially fatal pulmonary complication of SCD, characterized by intravascular pulmonary red cell sickling. The clinical spectrum spans from a mild pneumonic illness to life-threatening acute respiratory distress syndrome and multi-organ failure. It is commonly heralded by a fall in alveolar oxygen tension, leading to polymerization of sickle red cells, vaso-occlusion, decreased pulmonary blood flow, and hypoxia. Cytokines, such as vascular cell adhesion molecule 1 are critical in the development of ACS, as it enhances the adherence of red cells to the pulmonary endothelial cells, thus exacerbating vaso-occlusion and hypoxia. ${ }^{4}$ Some identified risk factors for the development of this condition include splenectomy,,$\frac{5}{}$ abdominal surgery,,$\underline{a}$ asthma,, infection,,$\underline{8}$ fat emboli, and sickle vasoocclusive pain. $\underline{9}$

If untreated, severe cases of ACS may progress to persistent hypoxemia and hypercapnia, resulting in respiratory failure and invariably death. ${ }^{-}$It has been estimated that up to $50 \%$ of patients with SCD could have at least one episode of ACS in their lifetime. $\stackrel{10}{\text {. }}$

Red cell exchange (RCE) (erythrocytapheresis) is an effective important component of the management of sickle-related complications. .11 Common indications include ACS, stroke, multi-organ failure syndrome, and priapism. $\stackrel{11}{\underline{12}} \mathrm{RCE}$ is superior to simple transfusion in that it reduces the percentage of circulating sickle cells while increasing the red cell oxygen carrying capacity, without causing a corresponding increase in blood viscosity and body iron. Increased blood viscosity alters blood rheology and predisposes to ischemic adverse events such as vaso-occlusive crises and stroke while iron overload causes marked organ tissue damage, with an increase in disease morbidity and mortality. $\underline{13}, \underline{14}, \underline{15}, \underline{16}$

Documented effects of RCE in the setting of ACS include improved tissue oxygenation, changes in $\mathrm{Hb}$ oxygen affinity and blood oxygen pressure, increase in transcutaneous oxygen saturation $\left(\mathrm{SpO}_{2}\right)$, increased $\mathrm{HbA}$ content with reduced $\mathrm{HbS}$ fraction and reduced WBC count and inflammatory markers. $\underline{17}, \underline{18}, \underline{19}, \underline{20}, \underline{21}$

There is a paucity of literature on the timelines for resolution of parameters (such as $\mathrm{SpO}_{2}$ and blood counts) in SCD patients with ACS, who had received RCE, particularly automated-RCE (auto-RCE). The aim of this study was, therefore, to evaluate the spectrum of changes in the blood counts and $\mathrm{SpO}_{2}$ in $\mathrm{SCD}$ patients with ACS, post auto-RCE, with a view to highlighting changes in counts at symptom resolution and the timelines for saturation to become optimized.

\section{SUBJECTS AND METHODS}

This was a retrospective study, carried out at the red cell unit of the University College London Hospital, involving confirmed SCD patients aged $\geq 18$ years who presented to the emergency room with ACS between the months of January 2014 and January 2016. Diagnostic features considered in keeping with ACS included fever, cough, chest pain, shortness of breath, reduced $\mathrm{SpO}_{2}$, hemoptysis, and suggestive chest X-ray findings with or without preceding history of acute pain crisis. ${ }^{22}$ Other inclusion criteria were hospitalization on account of ACS $\geq 24 \mathrm{~h}$ and at least one session of auto-RCE in the index admission.

The data of individual patients were retrieved from the departmental paper medical notes as well as the hospital's patient data program. Sociodemographic information, date and time of admission, symptoms at presentation, date and time of auto-RCE procedures, serial recordings of $\mathrm{SpO}_{2}$ on room air (from the point of admission till resolution of chest symptoms and discharge from hospital), time of resolution of chest symptoms post-RCE and length of hospitalization were extracted. The results of serial blood counts: WBC count, $\mathrm{Hb}$ concentration, platelet count, absolute neutrophil count (ANC), absolute lymphocyte count, platelet count and the neutrophil-lymphocyte ratio (NLR) were similarly retrieved from the electronic patient data program of the unit. All data were entered into Statistical Package for Social Sciences version 20.0 (SPSS Inc., Chicago, IL, USA) computer software for further analyses. 
7/20/2017 Effect of automated red cell exchanges on oxygen saturation on-air, blood parameters and length of hospitalization in sickle cell disease pa...

The time for $\mathrm{SpO}_{2}$ (in room air) to increase to $\geq 95 \%, \underline{22}$ was noted for each patient, and this was taken as the time for significant improvement in $\mathrm{SpO}_{2}$ to have taken place, post auto-RCE. The means of blood counts before auto-RCE were compared with values recorded at the point of symptom resolution using the Student's $t$-test while the level of statistical significance was set at $P \leq 0.05$ (at $95 \%$ confidence interval).

\section{RESULTS}

A total of 5 patients, with mean age of $40.40 \pm 5.12$ years, including $4 \mathrm{HbSS}$ and $1 \mathrm{HbSC}$; two males and three females were studied.

The mean of $\mathrm{Hb}$ concentration was significantly higher in all patients at the point of resolution of symptoms compared to the value recorded before auto-RCE $(105.40 \pm 7.90 \mathrm{~g} / \mathrm{L}$ vs. $81.80 \pm 8.53, \mathrm{P}=0.01$, Table 1).

Correspondingly, the means of total white and ANCs were significantly lower at the point of symptom resolution in all patients, compared with values before auto-RCE $\left(9.47 \pm 3.52 \times 10^{9} / \mathrm{L}\right.$ vs. $14.03 \pm 2.41 \times$ $10^{9} / \mathrm{L} ; 5.21 \pm 3.44 \times 10^{9} / \mathrm{L}$ vs. $8.26 \pm 4.88 \times 10^{9} / \mathrm{L}, P$ values 0.03 and 0.04 , respectively, Table 1$)$.

The means of platelet count and NLR were lower at the point of symptom resolution in all patients compared with values before auto-RCE. However, these differences were not statistically significant $(P>$ 0.05 , Table 1).

The median time of $\mathrm{SpO}_{2}$ recovery in all patients was $24 \mathrm{~h}(6-96 \mathrm{~h}) ; 60 \%(3 / 5)$ of all patients achieved optimal $\mathrm{SpO}_{2}$ within $24 \mathrm{~h}$ post auto-RCE, whereas $80 \%$ (4/5) achieved this within $48 \mathrm{~h}$. Only one patient was admitted to the intensive care unit (ICU) at presentation; discharge from ICU occurred $24 \mathrm{~h}$ after autoRCE.

By the time of symptom resolution, the WCC and platelet counts had returned to normal in $60 \%(3 / 5)$ of study patients. The average duration of chest symptoms, post auto-RCE, was 105.6 (24-240) h while mean in-patient stay was $244.8(144-456) \mathrm{h}$.

\section{DISCUSSION}

The median time for $\mathrm{SpO}_{2}$ to increase to $\geq 95 \%$ post auto-RCE in this study was $24 \mathrm{~h}$. The $\mathrm{SpO}_{2}$ cut-off of $\geq 95 \%$ was chosen as it conforms to the British Committee for Standards in Haematology guidelines on ACS; it is believed to represent the point of optimal oxygen-carrying capacity of the red cells. $\frac{22}{}$ Increasing hypoxemia and hypercapnia have been shown to be important hallmarks of ACS and in severe cases can progress to death from acute hypoxic respiratory failure. $\frac{10}{}$ Auto-RCE for ACS with HbAA red cells can provide a rapid and dramatic improvement in oxygen carrying capacity which reverses hypoxaemia and hypercapnia, commonly reflected as an increase in $\mathrm{SpO}_{2} \cdot \frac{23}{3}$ The timelines required for this to take place has however not been sufficiently studied. $\underline{18}$

In this study, $60 \%(3 / 5)$ and $80 \%(4 / 5)$ of patients achieved optimal tissue oxygenation in $24 \mathrm{~h}$ and $48 \mathrm{~h}$, post auto-RCE, respectively. The above timelines demonstrated in this study could well indicate the times expected to achieve management goals in patients with ACS on auto-RCE. Physicians could, therefore, find this information handy in making management decisions as well as during counseling of patients/relatives on clinical recovery and possible length of hospital stay. Further study of larger subjects is suggested to confirm our finding and generate more data on auto-RCE in SCD patients with ACS. Interestingly, one of the patients was observed to have achieved optimal $\mathrm{SpO}_{2}(96 \%)$ by $96 \mathrm{~h}$ post autoRCE but desaturated over the next 5-9 days, subsequently stabilizing over the next 11-12 days. It is important to note that persistent desaturation post-RCE could, in fact, be a "red flag" for further investigation for documented conditions such as unresolved chest infection, and other co-morbidities such as asthma, pulmonary hypertension and the presence of chronic sickle lung disease. ${ }^{22}$ These conditions influence $\mathrm{SpO}_{2}$ and may require specific interventions as applicable. The index patient had underlying pulmonary hypertension secondary to past episodes of ACS, which probably explains the pattern of $\mathrm{SpO}_{2}$ observed. 
7/20/2017 Effect of automated red cell exchanges on oxygen saturation on-air, blood parameters and length of hospitalization in sickle cell disease pa...

In this study, we observed that the WBC and ANC showed a uniform decrease in patients post auto-RCE and remained significantly lower at the point of resolution of symptoms compared to the values obtained before the exchange. Our finding is in agreement with the earlier report of Marques et al., who observed a reduction in WBC count post-RCE. ${ }^{21}$ This could be as a result of the reported post-RCE blunting of inflammation; $\underline{\underline{20}}$ white cells, particularly neutrophils tend to increase in inflammation, as part of the acute phase response. $\frac{24}{}$ The $\mathrm{Hb}$ concentration increased progressively in all the patients, postprocedure and remained significantly higher than preexchange levels at the point of symptom resolution, this is consistent with the documented increase in Hb content which occurs post-RCE. 19

The average length of inpatient hospitalization in this study is similar to that reported by Vichinsky et al. in adults patients (10.2 days vs. 10.5 days, respectively) but higher than observed by Sprinkle et al. in children (10.2 days vs. 7 days, respectively). $\underline{9}, \underline{25}$ The average time for resolution of chest symptoms post auto-RCE (4.4 days) was shorter than the total inpatient hospitalization time in this study. Some of our patients had extended hospital stay due to concurrent co-morbidities such as renal impairment and pulmonary hypertension. It is, therefore, likely that the in-patient hospitalization, post auto-RCE could be similar to that observed in children (and may parallel the time of resolution of chest symptoms), in the absence of significant co-morbidities. There is a need to investigate for concurrent co-morbidities in SCD patients with ACS, who may need extended hospitalization post auto-RCE.

\section{Limitations of this study}

The small sample size could have affected the power of our conclusions.

\section{CONCLUSION}

Auto-RCE continues to show tremendous benefit in the setting of ACS, particularly with regards to prompt restoration of $\mathrm{SpO}_{2}$ and timely resolution of presenting chest symptoms. It, therefore, has remarkable potential in significantly reducing lengths of ICU and hospital stay in SCD patients with this lifethreatening complication.

\section{Financial support and sponsorship}

Nil.

\section{Conflicts of interest}

There are no conflicts of interest.

\section{REFERENCES}

1. Lal A, Vichinsky EP. Sickle cell disease. In: Hoffbrand AV, Catovsky D, Tuddenhan EG, editors. Postgraduate Hematology. 5th ed. Oxford: Blackwell Publishing; 2005. p. 104.

2. Aneke JC, Adegoke AO, Oyekunle AA, Osho PO, Sanusi AA, Okocha EC, et al. Degrees of kidney disease in Nigerian adults with sickle-cell disease. Med Princ Pract. 2014;23:271-4. [PubMed: 24751459]

3. Okpala I. The intriguing contribution of white blood cells to sickle cell disease - A red cell disorder. Blood Rev. 2004;18:65-73. [PubMed: 14684149]

4. Stuart MJ, Setty BN. Sickle cell acute chest syndrome: Pathogenesis and rationale for treatment. Blood. 1999;94:1555-60. [PubMed: 10477680]

5. Ghantous S, Al Mulhim S, Al Faris N, Abushullaih B, Shalak F, Yazbeck S. Acute chest syndrome after splenectomy in children with sickle cell disease. J Pediatr Surg. 2008;43:861-4. [PubMed: 18485954]

6. Kokoska ER, West KW, Carney DE, Engum SE, Heiny ME, Rescorla FJ. Risk factors for acute chest syndrome in children with sickle cell disease undergoing abdominal surgery. J Pediatr Surg. 2004;39:84850. [PubMed: 15185210]

7. Boyd JH, Macklin EA, Strunk RC, DeBaun MR. Asthma is associated with acute chest syndrome and pain in children with sickle cell anemia. Blood. 2006;108:2923-7. [PMCID: PMC1892235] 
[PubMed: 16690969]

8. Neumayr L, Lennette E, Kelly D, Earles A, Embury S, Groncy P, et al. Mycoplasma disease and acute chest syndrome in sickle cell disease. Pediatrics. 2003;112(1 Pt 1):87-95. [PubMed: 12837872]

9. Vichinsky EP, Neumayr LD, Earles AN, Williams R, Lennette ET, Dean D, et al. Causes and outcomes of the acute chest syndrome in sickle cell disease. National Acute Chest Syndrome Study Group. N Engl J Med. 2000;342:1855-65. [PubMed: 10861320]

10. Castro O, Brambilla DJ, Thorington B, Reindorf CA, Scott RB, Gillette P, et al. The acute chest syndrome in sickle cell disease: Incidence and risk factors. The Cooperative Study of Sickle Cell Disease. Blood. 1994;84:643-9. [PubMed: 7517723]

11. Swerdlow PS. Red cell exchange in sickle cell disease. Hematology Am Soc Hematol Educ Program. 2006;2006:48-53. [PubMed: 17124039]

12. Kim HC. Red cell exchange: Special focus on sickle cell disease. Hematology Am Soc Hematol Educ Program. 2014;2014:450-6. [PubMed: 25696893]

13. Thurston GB, Henderson NM, Jeng M. Effects of erythrocytapheresis transfusion on the viscoelasticity of sickle cell blood. Clin Hemorheol Microcirc. 2004;30:83-97. [PubMed: 15004333]

14. Thuret I. Post-transfusional iron overload in the haemoglobinopathies. C R Biol. 2013;336:164-72. [PubMed: 23643400]

15. Porter JB, Garbowski M. The pathophysiology of transfusional iron overload. Hematol Oncol Clin North Am. 2014;28:683-701, vi. [PubMed: 25064708]

16. Kim HC, Dugan NP, Silber JH, Martin MB, Schwartz E, Ohene-Frempong K, et al. Erythrocytapheresis therapy to reduce iron overload in chronically transfused patients with sickle cell disease. Blood. 1994;83:1136-42. [PubMed: 8111053]

17. Emre U, Miller ST, Gutierez M, Steiner P, Rao SP, Rao M. Effect of transfusion in acute chest syndrome of sickle cell disease. J Pediatr. 1995;127:901-4. [PubMed: 8523186]

18. Uchida K, Rackoff WR, Ohene-Frempong K, Kim HC, Reilly MP, Asakura T. Effect of erythrocytapheresis on arterial oxygen saturation and hemoglobin oxygen affinity in patients with sickle cell disease. Am J Hematol. 1998;59:5-8. [PubMed: 9723569]

19. Nifong TP, Domen RE. Oxygen saturation and hemoglobin A content in patients with sickle cell disease undergoing erythrocytapheresis. Ther Apher. 2002;6:390-3. [PubMed: 12423535]

20. Liem RI, O'Gorman MR, Brown DL. Effect of red cell exchange transfusion on plasma levels of inflammatory mediators in sickle cell patients with acute chest syndrome. Am J Hematol. 2004;76:19-25. [PubMed: 15114592]

21. Marques MB, Singh N, Reddy VV. Out with the bad and in with the good; red cell exchange, white cell reduction, and platelet reduction. J Clin Apher. 2014;29:220-7. [PubMed: 24828305]

22. Howard J, Hart N, Roberts-Harewood M, Cummins M, Awogbade M, Davis B. BCSH Committee.

Guideline on the management of acute chest syndrome in sickle cell disease. Br J Haematol. 2015;169:492-505. [PubMed: 25824256]

23. Turner JM, Kaplan JB, Cohen HW, Billett HH. Exchange versus simple transfusion for acute chest syndrome in sickle cell anemia adults. Transfusion. 2009;49:863-8. [PubMed: 19309475]

24. Ramaiah SK, Jaeschke H. Role of neutrophils in the pathogenesis of acute inflammatory liver injury. Toxicol Pathol. 2007;35:757-66. [PubMed: 17943649]

25. Sprinkle RH, Cole T, Smith S, Buchanan GR. Acute chest syndrome in children with sickle cell disease. A retrospective analysis of 100 hospitalized cases. Am J Pediatr Hematol Oncol. 1986;8:105-10.

[PubMed: 3740365] 
7/20/2017 Effect of automated red cell exchanges on oxygen saturation on-air, blood parameters and length of hospitalization in sickle cell disease pa...

Table 1

\begin{tabular}{lcccc} 
Hematological indices & $\begin{array}{c}\text { Before automated } \\
\text { red cell exchange }\end{array}$ & $\begin{array}{c}\text { At symptom } \\
\text { resolution }\end{array}$ & $P$ \\
\hline Hb concentration $(\mathrm{g} / \mathrm{L})$ & $81.80 \pm 8.53$ & $105.40 \pm 7.90$ & $0.01^{*}$ \\
WBC $\left(\times 10^{9} / \mathrm{L}\right)$ & $14.03 \pm 2.41$ & $9.47 \pm 3.52$ & $0.03^{*}$ \\
Platelet count $\left(\times 10^{9} / \mathrm{L}\right)$ & $261 \pm 41.92$ & $247.00 \pm 131.75$ & 0.85 \\
ANC $\left(\times 10^{9} / \mathrm{L}\right)$ & $8.26 \pm 4.88$ & $5.21 \pm 3.44$ & $0.04^{*}$ \\
ALC $\left(\times 10^{9} / \mathrm{L}\right)$ & $2.12 \pm 1.32$ & $1.52 \pm 1.14$ & 0.31 \\
NLR & $3.35 \pm 2.30$ & $2.90 \pm 1.79$ & 0.50 \\
\hline
\end{tabular}

*Significant $P$ values. $\mathrm{Hb}$ - Hemoglobin; WBC - White blood cell; ANC - Absolute neutrophil count; ALC - Absolute lymphocyte count; NLR - Neutrophil to lymphocyte ratio

Comparison of means and standard deviation of haematological indices before automated red cell exchange and at symptom resolution

Articles from Nigerian Medical Journal : Journal of the Nigeria Medical Association are provided here courtesy of Medknow Publications 